\title{
DEVELOPING STUDENTS' FACILITY IN COMMUNICATIVE INTERACTION TECHNIQUES OUTSIDE THE LANGUAGE LEARNING CLASSROOM AT NON-LINGUISTIC FACULTIES
}

\author{
Rimma Druzhinina \\ Pskov State University, Russian Federation
}

\begin{abstract}
The article focuses on some new insights into the effects of students' communicative interaction in the language learning process. The study offers some modes of utilizing the extra-curricular activities potential for generating an interaction environment where students venture into true communication. The syllabus of students' interaction within their extracurricular activities has been defined in the study in relation to the video conferencing technology. We have expanded the range of educational offerings while introducing some components of video conferencing into students' communicative learning: virtual meeting rooms, discussion forums, screen sharing. The topicality of the study consists in insufficient number of scientific works on aspects of students' communicative interaction within extracurricular activities in language learning. Hence the aim of the study is to propose theoretical justification and methodological development of utilizing the interaction potential within extra-curricular activities for students' communication training. Following the aim we have examined characteristics of students' communicative interactions within extra-curricular cases in language learning. We have elaborated some techniques and devices, identified some ways of generating communicative interaction dynamics for furthering students' communication training. We have verified the findings in our experimental practical work and have revealed the significance of students' interactions within extra-curricular activities for facilitating their communication potential in language learning.
\end{abstract}

Keywords: non-linguistic faculties, language learning process, extra-curricular activities, video conferencing technology, communication training, communicative interaction, taskbased learning, techniques and devices.

\section{Introduction}

Communication training is considered to be an important component in contemporary management education programs (Bavina, 2006; Denisova, 2004 and others). Foreign language teaching at faculties of management is based on communicative activities and can facilitate students' communication training. Scientists focus their research on students' communication training in foreign language teaching (Abdrahmanova, 2007; Gorbunova, 2008; Chunihina, 2013; Denisov, 2007; Shukurova, 2006), yet they devote it to language classroom 
Druzhinina, 2021. Developing Students' Facility in Communicative Interaction Techniques Outside the Language Learning Classroom at Non-Linguistic Faculties

teaching only. However, the time for language study is usually limited within rigid timescales at non-linguistic faculties. In our study we propose ways of utilizing the reserves of students' extra-curricular activities in foreign language teaching. There are no comprehensive studies that would reveal stages, methods, ways of communication training outside the language learning classroom. Our study examines some modes of utilizing extra-curricular activities potential for generating a communicative interaction environment where students venture into true communication.

Communicative interaction aspects in language learning in the university environment are examined in many works (Bim, 2001; Zimnyaya, 1984; Mil'rud \& Maksimova, 2000). Rubinshtejn S. L. defined interactions as a mutual influence process which determines the structure and the properties of a system (Rubinshtejn, 1976). Scientists consider foreign language contexts for communicative interaction situations (Bim, 2001; Mil'rud \& Maksimova, 2000), issues of organizing communicative interactions in the language learning process (Haleeva, 1989), examine skills within communicative interactions targeted at handling tasks (Bim, 2001). Communicative interactions are defined in scientific papers as coordinating activities aimed at achieving common targets within handling joint tasks (Chunihina, 2013). Information search, opinions positioning, topic expanding, information transfer, problem solving are expected to be targets within communicative interactions (Denisov, 2007). In our work we adhere to the view that communicative interactions involve establishing and maintaining contacts between individuals by means of the language facilities. A communicative contact occurs each time within the communicative interaction and involves information exchange to attain designated targets.

Communicative interaction issues within extra-curricular cases in language learning still seem to remain in many respects open for research. The most characteristic of exchanges in the context of the students' extra-curricular cases is a sense of purpose. Language is used to achieve a target and its successful use is seen in terms of a successful outcome to the event elaboration. It follows that performance objectives take priority over language learning for its own sake. It should be noted here that much of the language needed by management professionals would be transactional: getting what is necessary and persuading others with the course of actions proposed.

Hence the topicality of the study consists in insufficient number of scientific papers on aspects of students' communicative interactions within extra-curricular cases in language learning.

The aim of the study is to propose some theoretical justification and methodological development of utilizing the interaction potential within extracurricular cases for students' communication training in language learning. 
The object of the study is the process of organizing extra-curricular interactions in students' language clubs at faculties of management. The subject of the study is the process of developing students' communication potential in their interactions within extra-curricular events elaboration at faculties of management.

The tasks of the study consist in:

- examining characteristics of students' communicative interactions within their extra-curricular cases in language learning;

- elaborating techniques and devices of generating communicative interaction dynamics for furthering students' communication training;

- approbating the findings within students' extra-curricular cases at faculties of management.

The following research methods have been applied in our study: scientific literature analysis, work experience analysis, pedagogical observation, pedagogical experiment, data analysis.

\section{Methodology and Empirical Research}

Our study offers some modes of utilizing the extra-curricular activities potential for generating an interaction environment where students venture into true communication. The syllabus of extra-curricular activities in our experience has been structured in relation to students' events elaboration and performance in the language club within distance learning technologies.

Characteristics inherent in any pedagogical technology are described in many research papers. They are the cyclical nature of actions, repeatability, logical sequences of actions, rationing of interaction (Bavina, 2006). In foreign language teaching pedagogical technologies are described as specially organized, time-based procedures for teaching communicative skills and as based on a system of goals, content, methods, means and forms of communication training (Levchenko, 2005). Communication training in foreign language teaching of today tends to integrate elements from various technologies, communicative interaction being the key element of the learning process.

Distance learning technologies are being examined by contemporary scholars. Bates (1991) singles out three generations of distance learning associated with the historical development of production, distribution and communication technologies. The main focus of the first two generations of distance teaching consisted in the production and distribution of teaching materials. The third generation, in his opinion, is based on new technologies of interactive communication (the facilities of new telecommunication and 
Druzhinina, 2021. Developing Students' Facility in Communicative Interaction Techniques

Outside the Language Learning Classroom at Non-Linguistic Faculties

computer technologies). New communication technologies are considered to blur the distinction between traditional and distant learning. They have potential uses in both situations (Bates, 1991).

In our work we utilize a video conference learning scheme in accordance with the ideas of contemporary scholars. Lynne Coventry (2007) introduces a video conference learning framework. It includes active construction of knowledge, peer interaction, development of oral explanation skills, motivating feedback received from others. Lynne Coventry's model emphasizes the importance of construction and dialog and the dialog is defined as learning through discussion and reflection and as a fundamental component of video conference learning (Coventry, 2007).

The extra-curricular activities sessions in our experience were carried out in virtual Zoom setups. We consider Zoom as an effective video conferencing tool to hold virtual language club sessions. We utilize multiple features provided by Zoom: screen sharing, live chats, video recording and others.

The basic fabric of the club activities was handling tasks within real situations of students' events elaboration. Setting up the task thoroughly was essential to guide the club participants in the situations they were to deal with, in the things they were to communicate. Each task would rely on much input from the participants (on their research materials) and on the teacher's frameworks. Handling tasks was associated with obtaining the interaction product and, for that purpose, with generating a conversation. Such performance areas as structure, process, function, cause, effect, advantage were involved. Within them the language of clarifying, restating, confirming, concluding was of significance.

Each task related to the overall objectives of the case. Depending on the stage of the event elaboration process the tasks included the following activities:

1) identifying themes, submitting hypotheses, discussing resources;

2) creating teams, forecasting actions, discussing materials;

3) integrating ideas, allocating actions, developing scenarios;

4) mastering language materials and speech behaviour;

5) analyzing the experience.

The sequence has been borrowed from one of the instruction cycle models elaborated by John Gibbons. The model characterizes the stages through which language learning activities usually proceed and the order in which the stages occur:

1) the introduction to the task and to the performance itself orients learners towards the topic and the situation;

2) the preparation includes organizing resources, constructing the environment, positioning participants, identifying materials;

3) the performance stage relates to the model elaboration and actual doing of the activity; 
4) the feedback and the follow up stages are stages where the problems are worked on and the input for another cycle is formed (Gibbons, 1984).

Thus students' communicative interactions took place at each stage of the process. Each time it was aimed at handling the task and creating the targeted communicative product.

In the beginning the teacher would give an agenda for the session by screen sharing visuals. It was essential to use plenty of pictures, videos, documents, graphs, which would create a better understanding of the task and its topic. That gave the participants a better idea of what was to be covered, of the activities they were to be engaged in.

Then Zoom's breakout rooms feature was utilized to assign the participants into groups for a designated period of time so that they could interact within handling the designated task together.

In scientific papers we find descriptions of strategies for group dynamics (Kral, 1997). In our experience we often applied three of them: "Dyad", "Small Group", "Unified Group”. Each task handling session started with "Dyad" activities in breakout rooms. "Dyad" activities gave participants an opportunity to work one-to-one with the peer in the session. Through these activities peers began to feel more comfortable in sharing and discussing their findings and ideas. Each dyad would discuss, for example, their research findings for at least ten minutes to outline the most important points. In the two-way communication each of the participants could use the option to speak and to position ideas for a substantial period of time.

Participants were usually aware of the necessary skills for a successful group cooperation: how to get information from the interlocutor, how to respond to questions, how to generate phrases and question forms. They usually tried to process the skills they had practiced in their regular classes and to integrate them into extra-curricular interactions with their peers.

After the dyads were brought back to the original call the breakout rooms facility was used to combine dyads into small groups of four to expand the interaction for handling the task. Each small group in its turn was taken to its breakout room for a period of time to interact. In breakout rooms participants incorporated into their discussion various virtual elements such as visuals, documents, messages. They shared the screen presenting their files and outlining their ideas. They also used the whiteboard feature to explain the key issues. The teacher joined each small group room and facilitated the discussion. The group handled the task in a given time and reported back to the original call.

At the last stage of the task within the "Unified Group" strategy, the participants worked together to integrate the most important findings and ideas into a unified product, the output for the designated task (e.g. the event script). 
Druzhinina, 2021. Developing Students' Facility in Communicative Interaction Techniques

Outside the Language Learning Classroom at Non-Linguistic Faculties

The participants used the Zoom feature of "raising hands" to enter the interaction. They had an opportunity to utilize annotation tools to highlight particular corrections and to comment on particular areas, just sharing the screen and the whiteboard facility. Thus they could view and edit documents. They could also record and save segments of the session and re-watch or reread them when it was necessary.

Before learners embark on the club interactions they should familiarize themselves in their regular classrooms with major language patterns to be able to form meaningful utterances in their talk.

In Clifford Prator's research we find descriptions of major phases in language teaching, specifically, manipulative and communicative ones (Prator, 1965). Manipulative activities are supposed to give learners mastery of language patterns but sometimes leave them unprepared to carry on a basic conversation outside the class. Conversation is defined in scientific papers as the interchange of information by spoken words (Dobson, 1992).

In our study we consider guided conversation practice to be a reliable route to true communication. Within the club sessions learners maintained a controlled interaction in which they conversed using their research materials and frameworks imposed by the teacher. In scientific literature certain didactic structures are introduced and examined. They are called frameworks and can be considered as activities schemes used to encourage learners' interaction to help them to generate language and to build conversations. At later interaction stages framework supports can be gradually removed and learners can gradually enter their free communication (Ellis \& Johnson,1996).

This is an example of the framework used in our study within students' extra-curricular cases for practicing the language of alternatives (Table 1).

Table 1 Advantages and Disadvantages Interaction Framework

\begin{tabular}{|c|c|c|c|}
\hline \multicolumn{4}{|c|}{ Problem } \\
\hline \multicolumn{4}{|c|}{} \\
\hline Small group A solution & Small group B solution \\
\hline Advantage & Disadvantage & Advantage & Disadvantage \\
\hline Advantage & Disadvantage & Advantage & Disadvantage \\
\hline Advantage & Disadvantage & Advantage & Disadvantage \\
\hline \multicolumn{5}{|c|}{ Evaluation } \\
\hline \\
\hline \multicolumn{4}{|c|}{$\bullet$} \\
\hline \\
\hline
\end{tabular}


The teacher suggested at the outset that, while handling the task the participants were to follow the procedures outlined in the framework. One participant was to control the procedures writing down proposals as they were being made.

In the carefully controlled conversation format a list of techniques and devices was applied (Dobson, 1992). Questions and answers aspect was of the utmost importance in generating conversation dynamics. Questions and answers in communicative interactions of the club participants related to real situations. Actual information was sought and factual replies were expected in the conversations.

Another aspect of conversation dynamics was connected with building comments on one another (Dobson, 1992). For example, a speaker made a comment in response to a comment just given by his interlocutor or he formed a series of comments (or even a short monologue). His interlocutors responded with comments or questions of their own. Occasionally speakers began one statement and then switched to another, each time signaling the next intent with special expressions.

Thus in conversations interlocutors had to follow some conversation strategies. Conversation strategies were means of keeping interactions continued. Researchers propose lists of conversation strategy signals, gambits being one of the signals. Gambits are words or phrases that help learners to regulate the flow of the talk and to get the success of it. They are remarks intended to start a conversation, to make a telling point, to introduce a topic, to make a calculated move, to expand the subject, to structure turn-taking (Ellis \& Johnson, 1996).

Some conversation strategy signals processed within students extracurricular cases are introduced in Table 2.

Table 2 Conversation Strategy Signals

\begin{tabular}{|l|l|}
\hline \multicolumn{1}{|c|}{ Some functions } & \multicolumn{1}{c|}{ Some gambits } \\
\hline Various aspects of a topic & $\begin{array}{l}\text { First of all, it is important to note, a word must be said about, } \\
\text { another thing is, believe it or not, to be realistic, to illustrate the } \\
\text { point, a case in point is, etc. }\end{array}$ \\
\hline Giving opinions & $\begin{array}{l}\text { I think, my guess is, I am sure that, to my mind, I personally } \\
\text { believe, it seems to me, let me tell you, I am certain, I rather } \\
\text { think that, as I see it, in my case, etc. }\end{array}$ \\
\hline Action strategies & $\begin{array}{l}\text { We must bear in mind, we mustn't forget, we have to } \\
\text { remember, now let us look at, I can't accept your idea, I can } \\
\text { see your point of view, why don't we do the following, what } \\
\text { we have in mind is, here is what we shall do, etc. }\end{array}$ \\
\hline
\end{tabular}


Druzhinina, 2021. Developing Students' Facility in Communicative Interaction Techniques Outside the Language Learning Classroom at Non-Linguistic Faculties

\begin{tabular}{|l|l|}
\hline Subject expansion & $\begin{array}{l}\text { In addition, I might add that, there is also, moreover, the main } \\
\text { advantage is, besides, afterwards, furthermore, what is more, } \\
\text { consequently, in case of, and another thing, the reason why, } \\
\text { etc. }\end{array}$ \\
\hline Giving arguments & $\begin{array}{l}\text { Let me give an example, to illustrate this point let us consider, } \\
\text { it has an advantage over, in fact, I'd like to give some details } \\
\text { about, you do realize that, the point is that, as an example, for } \\
\text { one thing, ordinarily, etc. }\end{array}$ \\
\hline Prioritizing & $\begin{array}{l}\text { Primarily, the main point is, essentially, of a primary concern, } \\
\text { is worth considering, in most cases, notably, chiefly, mainly, it } \\
\text { has an advantage over, I tend to favor, it is important to view, } \\
\text { it is worth to introduce, above all, namely, etc. }\end{array}$ \\
\hline Conclusion & $\begin{array}{l}\text { On the whole, for the most part, as a matter of course, by and } \\
\text { large, to sum up, in brief, to go over the main points, that } \\
\text { covers the task, in general, in conclusion, finally, lastly, let us } \\
\text { conclude, to summarize the ideas, etc. }\end{array}$ \\
\hline
\end{tabular}

Thus for each performance area a bank of the key functions and selected language was given to back learners performance.

\section{Experiential Learning and Research Results}

In our study the experimental work was conducted over a period of March 2020 - December 2020 and incorporated approbating some extra-curricular interaction aspects within the students' event elaboration at faculties of management. Empirical training was organized for a 10-person experimental group of the language club members. The learners of the experimental group underwent task-based learning within the students' extra-curricular case. 80 minutes training periods were conducted twice a week for one term. The learners of the control group were taught only by traditional teacher-based methods.

The level of English for all the learners engaged was estimated between B1 and B2 according to the standards of the Common European Framework of Reference for Languages. At the initial and at the final phases the learners of both groups were asked to interact in pairs on the proposed communicative task. The learners of both groups demonstrated a similar moderate level of the communicative interaction skills (dialogue and polylogue skills) at the initial phase. A comparison of the initial and the final evaluation demonstrated that though at the initial phase the results of the two groups differed insignificantly, at the final phase the learners of the experimental group obtained higher scores.

The emphasis was on evaluating the success of the communicative interaction:

- $\quad$ if the learners were active within handling the task; 
- $\quad$ if the learners were cooperative within handling some aspects of the task;

- $\quad$ if the learners were not cooperative within handling the task.

The interaction process was video recorded and then transcribed. The performance progress scale applied within the experiment was based on findings from scientific works (Ellis \& Johnson,1996). An example of a performance progress scale utilized in our study is shown in Table 3.

\section{Table 3 Performance Progress Scale}

\section{Progress level 1}

The learner can handle long periods of interactions. His messages are well organized. He uses a wide range of the language patterns adequate for the needs of the interaction. He has full command of the language patterns. Each new point is clearly signaled by him.

Follow up. The learner is a competent speaker who will mainly need to work on increasing the range and accuracy.

\section{Progress level 2}

The learner is able to maintain interactions. A number of designated language patterns are known to him. He uses them with confidence in all but the most demanding situations. His communication is effective on most occasions. But he sometimes has to talk around an idea.

Follow up. The learner will need to work on the accuracy of the structure and vocabulary and the appropriacy of different kinds of language.

\section{Progress level 3}

The learner can "survive" in a communicative interaction but he is rather limited in the designated language patterns. He is sometimes unaware of the nuances of careful choice of language patterns. His responses are generally short with little elaboration.

Follow up. The learner has a long way to go to increase his communicative effectiveness in interactions.

The performance progress scale was developed with regard to the learners utterances (the number of the language items to convey the right meaning). The language items examined were those of the most common language patterns referred to as conversation strategy signals (gambits). To carry out the evaluation we determined the learners' communicative interaction entry and exit progress levels. For that we used video recordings which helped us to observe how the learners' progress matched the performance scale points.

Observing the learners' communicative interaction in both groups we noticed much more attempts with the club participants to use gambits as language tools to regulate the smooth flow of the conversation in the end of the experiential work (Table 4). 
Druzhinina, 2021. Developing Students' Facility in Communicative Interaction Techniques

Outside the Language Learning Classroom at Non-Linguistic Faculties

Table 4 Recycling Target Language Patterns in the Control and Experimental Groups (cases count)

\begin{tabular}{|c|c|c|c|c|c|}
\hline \multicolumn{2}{|c|}{$\begin{array}{c}\text { Control group (average } \\
\text { number of cases at the } \\
\text { assessment sessions) }\end{array}$} & \multicolumn{2}{|c|}{$\begin{array}{c}\text { Experimental group } \\
\text { (average number of cases at } \\
\text { the assessment sessions) }\end{array}$} & $\begin{array}{c}\text { Dynamics from pre-experiment } \\
\text { to post-experiment testing } \\
\text { average number of cases at the } \\
\text { assessment sessions) }\end{array}$ \\
\hline Pre- & Post- & Pre- & Post- & CG & EG \\
\hline 8 & 14 & 16 & 30 & 6 & 14 \\
\hline
\end{tabular}

The data obtained show higher increment in the number of the recycled language patterns in the learners' communicative interaction in the experimental group as compared to the control group which gives evidence as to the effectiveness of the guided communicative interaction technique within students' extra-curricular cases (Figure 1).

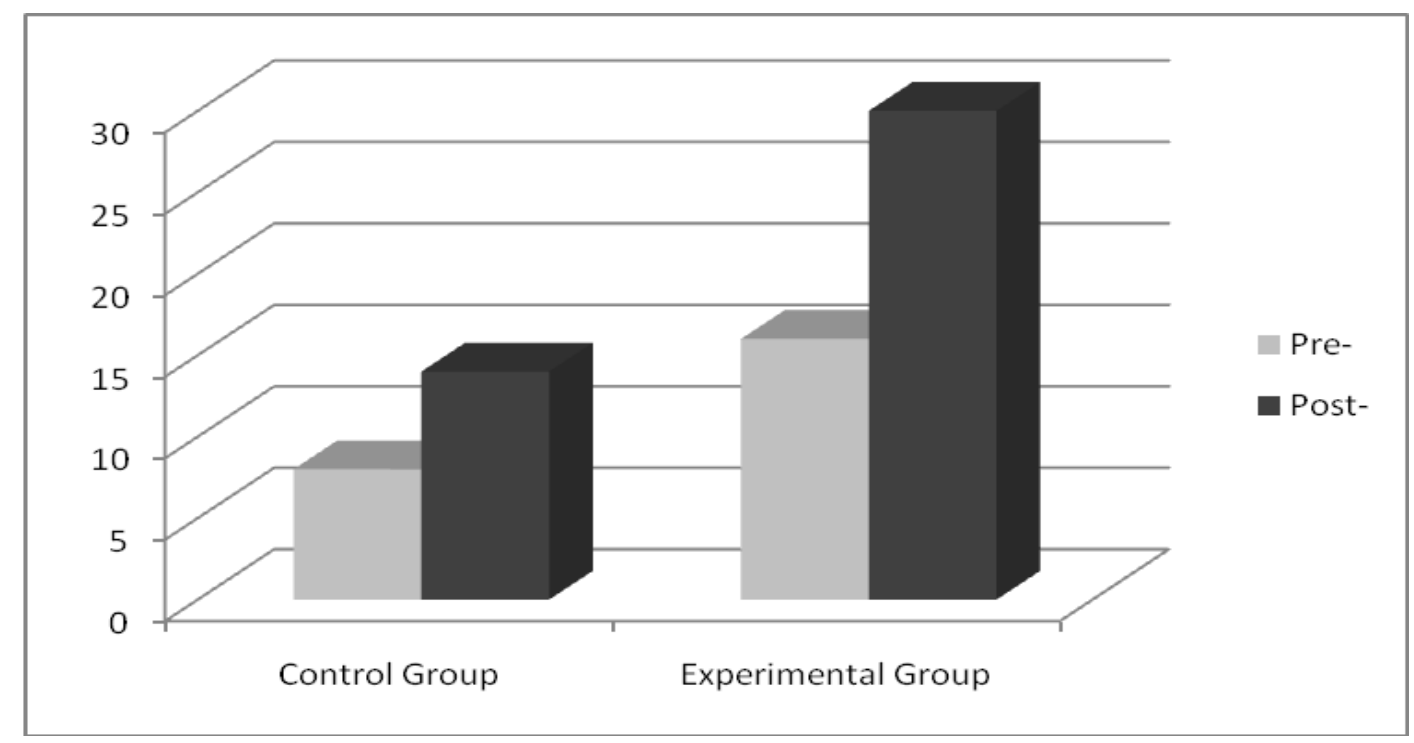

Figure 1 Dynamics in Recycling Target Language Patterns in the Control and Experimental Groups (cases count)

Thus having performed in the language club during a designated period of time the students on the whole have contributed to the development of their conversation potential. They demonstrated a stronger confidence in speaking than their counterparts in the control group.

\section{Conclusion}

In our study we have explored some effects of students' communicative interactions for their communication training in the language learning process. 
To adjust to fast changing needs of labor markets university graduates should be prepared for the dialogic character of the contemporary professional environment. However, as experience shows, university students at nonlinguistic faculties often lack skills for foreign language communicative interaction outside the language learning classroom. The presence of the problem is recognized in many scientific publications.

As literature analysis also evidences, the potential of extra-curricular activities in language learning seems to be underscored as a means of solving the problem. In our study a pattern of extra-curricular activities applied to a mini-group of the students' language club was integrated into the study process in the natural academic setting at faculties of management.

The experiential training gave insight into how the students interacted with each other while tackling the target tasks of the extra-curricular case. The study helped to elaborate strategies and to design some schemes for students' communicative interactions within extra-curricular cases. It enabled us to offer some guidance as to how to design frameworks for building conversations and generating the targeted language. We have elaborated some techniques and devices for furthering students' communication training within their extracurricular interactions in language learning.

Some technological issues were considered and applied. We managed to expand the range of educational offerings while introducing some components of video conferencing into students' communication training. There we identified some ways of generating communicative interaction dynamics for furthering students' communication training.

Thus, we have proposed some theoretical justification and methodological development for utilizing students' interaction potential within their extracurricular activities in language learning. We have verified the findings in our experimental practical work. The data obtained in the experiential learning period indicated positive dynamics in the students' performance progress within their extra-curricular interactions. Those who performed tasks within the extracurricular case presented their arguments in a more proficient manner, provided sufficient supporting materials to illustrate their arguments, used more relevant language clichés. In this way we have found some evidence of the significance of students' extra-curricular interactions for developing their communication potential in language learning at non-linguistic faculties.

As the size of the sample was rather small it cannot exemplify the students' community at large. So we consider this study as an exploratory investigation to identify most significant issues and trends for our further research. 
Druzhinina, 2021. Developing Students' Facility in Communicative Interaction Techniques

Outside the Language Learning Classroom at Non-Linguistic Faculties

\section{References}

Abdrahmanova, L. V. (2007). Formirovanie kommunikativnyh umenij u studentov tehnicheskogo vuza $v$ processe realizacii professional'no-diskussionnoj igrovoj tehnologii: na primere predmetnoj oblasti "Inostrannyj jazyk": dis. ... kand. pedagogicheskih nauk. Samara, Rossija: Abdrahmanova, L. V.

Bates, A. W. (1991). Third generation Distance Education: The challenge of New technology. Research in Distance Education, 3 (2), 10-15.

Bavina, P. A. (2006). Treningovye tehnologii v formirovanii kommunikativnoj kompetentnosti budushhih menedzherov: dis. ... kand. pedagogicheskih nauk. Sankt-Peterburg, Rossija: Bavina, P. A.

Bim, I. L. (2001). Nekotorye aktual'nye problemy sovremennogo obucheniya inostrannym yazykam. Inostrannye yazyki v shkole, 4(2001), 5-7

Chunihina, A. A. (2013). Metodika obucheniya kommunikativnym strategiyam vzaimodejstviya studentov napravleniya podgotovki (special'nosti) "Ekonomika" $v$ processe izucheniya inostrannogo yazyka: dis. ... kand. pedagogicheskih nauk. Moskva, Rossija: Chunihina, A. A.

Coventry, L. (2007). Video Conferencing in Higher Education. Institute for Computer Based Learning, Edinburgh: Heriot Watt University.

Denisov, V. N. (2007). Tekhnologiya razvitiya rechevogo vzaimodejstviya sub"ektov obucheniya pri izuchenii inostrannogo yazyka: dis. ... kand. pedagogicheskih nauk. Saratov, Rossija: Denisov, V.N.

Denisova, A. L. (2004). Metodologicheskie problemy podgotovki sovremennogo menedzhera $v$ innovacionnoj obrazovatel'noj srede: teoreticheskie aspekty i praktika. Samara, Rossija: Izd-vo SGJeA.

Dobson, J. M. (1992). Effective Techniques for English Conversation Groups. Washington, DC: US Information Agency.

Ellis, M., \& Johnson, Ch. (1996). Teaching Business English. Oxford, UK: Oxford University Press.

Gibbons, J. (1984). Sequencing in language syllabus design. In Trends in language syllabus design, ed. J. Read. Singapore: RELC/Singapore University Press.

Gorbunova, I. P. (2008). Formirovanie kommunikativnoj kompetentnosti u budushhih menedzherov $v$ processe prepodavanija inostrannogo jazyka $v$ sisteme srednego professional'nogo obrazovanija: dis. ... kand. pedagogicheskih nauk. Cheboksary, Rossija: Gorbunova, I. P.

Haleeva, I. I. (1989). Ponimanie inoyazychnogo ustnogo teksta kak akt mezhkul'turnoj kommunikacii. Glyadya v budushchee. Pervyj sovetsko-amerikanskij simpozium po teoreticheskim problemam prepodavaniya i izucheniya inostrannyh yazykov (17-21 oktyabrya 1989). Moskva, Rossija: MGLU, pp. 48-52.

Kral, Th. (1997). Teacher development. Making the right moves. Washington, DC.

Levchenko, O. Ju. (2005). Obuchenie inojazychnomu professional'no-znachimomu dialogicheskomu obshheniju na osnove autentichnyh social'nyh kontaktov (anglijskij jazyk, nejazykovyj vuz): dis. ... kand. pedagogicheskih nauk. Irkutsk, Rossija: Levchenko, O. Ju.

Mil'rud, R. P., \& Maksimova, I. R. (2000). Sovremennye konceptual'nye principy kommunikativnogo obucheniya inostrannym yazykam. Inostrannye yazyki $v$ shkole, 4 (2000), 9-15. 
Prator, Clifford H. (1965). Development of a Manipulation-Communication Scale. NAFSA Studies and Papers, English Language Series, No.10, March 1965.

Rubinshtejn, S. L. (1976). Problemy obshchej psihologii. Moskva, Rossija: Pedagogika.

Shukurova, I. V. (2006). Razvitie kommunikativnoj kompetentnosti studentov tekhnicheskih special'nostejdis. ... kand. pedagogicheskih nauk. Moskva, Rossija: Shukurova, I.V.

Zimnyaya, I. A. (1984). Rechevaya deyatel'nost' i rechevoe povedenie $v$ obuchenii inostrannomu yazyku. Sb. nauchnyh trudov MGPIIYA. Moskva, Rossija, 3-10. 